\title{
Lidwa Pusaka Application in Learning Hadith
}

\author{
$1^{\text {st }}$ Dadah $^{1}, 2^{\text {nd }}$ Casram $^{1}, 3^{\text {rd }}$ Ecep Ismail ${ }^{1}$ \\ \{ddah9440@gmail.com ${ }^{1}$ \} \\ UIN Sunan Gunung Djati, Faculty of Ushuluddin, Bandung, West Java, Indonesia ${ }^{1}$
}

\begin{abstract}
This study focuses on Lidwa Pusaka application in learning and teaching hadìth. Lidwa Pusaka or Lembaga Ilmu dan Da'wah serta Publikasi Sarana Keagamaan, The Institute of Islamic Science, Da'wa and Publication of Religious Facilities, is Indonesian computational application of hadīth that initiated by Indonesian students who studied in the Middle East. The application uses 62,000 hadīths that taken from nine books of hadith collections (kutub al-tis'ah). It can be used to search the meaning of hadith and its transmission. This study use the Lidwa Pusaka application in teaching hadith among students of Hadith Department at UIN Sunan Gunung Djati Bandung, using learning media approach. It is a study that analyze the relationship of two variables and then simultaneously sharing rows and columns of contingency tables. This study shows that the use of Lidwa Pusaka application is very effective in supporting the success of learning hadīth and among students. There are $75 \%$ of students who satisfied in learning hadīth using the application, $21 \%$ who quite satisfied, and $4 \%$ who did not satisfy.
\end{abstract}

Keywords: Lidwa Pusaka application; hadith; student; Hadith Department.

\section{Introduction}

There is a new development of hadīth or Muhammad's words collections in the early modern period. Since the twentieth century, hadīth scholars used some computational softwares and applications. These applications certainly can help researchers and common people in learning hadīth. Everyone who learn hadìth can more easier to search hadīth using the application [1].

It is different from the development of hadith in the early period of Islam in seventh century. Muslims cannot get hadìth directly. It is no many Muslims who able to understand the hadīth.

Many scholars then compiled hadīth into several collections, such as Șahīh al-Bukhārī, Șahīh Muslim, Sunan Abū Dāwud, Sunan al-Tirmidhī, Sunan al-Nasā̄ō, Muwatta' Mālik, Musnad Ahmad, Sunan al-Dārimī, and others [2].

Since the period of middle age of Islam, the hadith knowledge have increased. It is a period when hadīth scholars can studied systematically and easier to search hadīth in some collections of hadīth. While, another hadīth scholars began to analyse and evaluate some hadìths in several collections [3].

However, the hadith studies in classical period cannot be understood by students in modern period. The student of Islamic university cannot understand hadīth knowledge well. They do not have Arabic language skills. It is not easy to understand Arabic books of hadith collectons. 
This study will highlight the significance of computational program of hadith application, such as Lidwa Pustaka. The application is very interesting. It is not only for common people, but also students at the Islamic university. Lidwa Pusaka is a Indonesian computational program of hadīth application which use 62,000 hadīths that taken from nine books of hadith collections (kutub al-tis'ah). The application can be used to support the understanding of hadīth and hadīth knowledge [4].

The study focuses on the use of Lidwa Pusaka application in learning hadith among students of Hadīth Departement at UIN Sunan Gunung Djati Bandung. I used list of questionts on the student satisfaction in learning hadīth using Lidwa Pusaka application.

\section{Result and Discussion}

Lidwa Pusaka is an abbreviation of Lembaga Ilmu dan Da'wah serta Publikasi Sarana Keagamaan, The Institute of Islamic Science, Da'wa and Publication of Religious Facilities. It is an institution that engaged in the development of computational program and application of hadith. Lidwa Pusaka was created by Indonesian students who studied in the Middle East [5].

The hadīth application contains 62,000 hadīth that taken from nine books of hadìth collections (kutub al-tis'ah), such as Șah̄ịh al-Bukhārī, Șaḥ̄ḥ Muslim, Sunan Abū Dāwud, Sunan al-Tirmidhī, Sunan al-Nasā' '̄, Sunan Ibn Majah, Muwatta' Mālik, Musnad Ahmad, Sunan al-Dārimī [6].

There are some utilities of Lidwa Pusaka application that used by students in their learnings: 1) It can be accessed more easier using Laptop, PC, and android; 2) There is menu option to search hadīth; 3) The application already supported copy and paste menu of Arabic text and its translations into Indonesian; 4) It also displayed menu of type and font color that can be customized into user comfort; 5) It provides hadīth index based on certain theme; 6) Provides a menu to see Hadith's Hadith categorization degree, 7) The description of the narrators of hadith can be obtained easily, 8) Can add notes with user language, 9) Validation of books can be justified, because this software contains a complete source with, title, book name, page, juz, city published, publisher and year publication [4].

Lidwa Pusaka application can be used by both offline and online using the internet [7]. Following picture show the steps of Lidwa Pustaka application when used by offline:

1) Open the program of Kitab 9 Imam, the nine books of imam, that already installed:

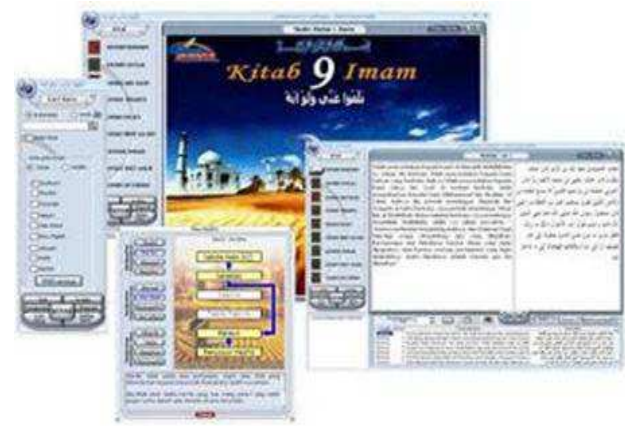

Figure 1. Kitab 9 Iman 
2) Use the search menu in order to search certain hadīth, the rawi or scholars who tale the hadīth, and book of hadīth collections which collected the hadīth. We can choose one of chapters of the collection of hadith, such as the prayer, zakat, fasting etc. We can also use certain words relating to the list of rawi and its biography or index. You should put the cursor in the search field, then type the keyword that will be searched in Arabic or Indonesian language.

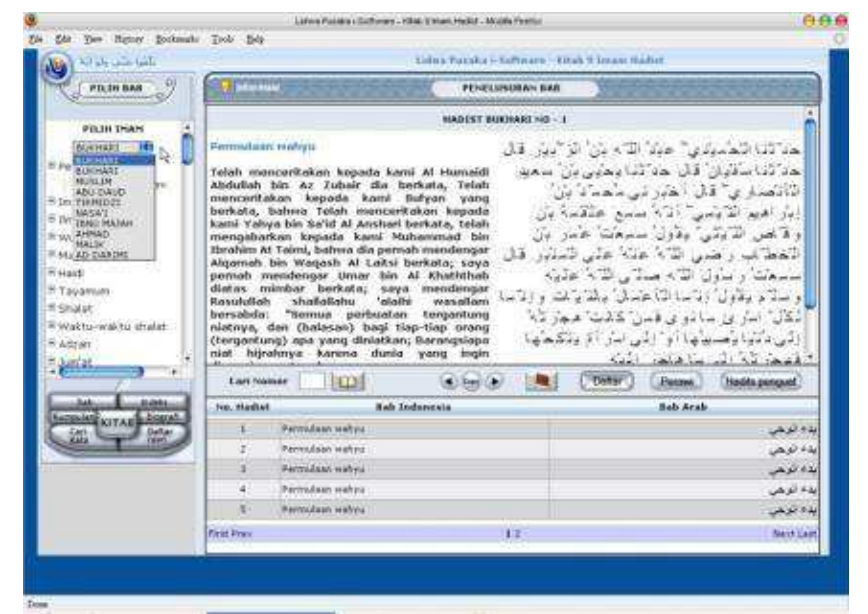

Figure 2. Search Menu Display

3) Following picture show the rawi names and their qualities in tale the hadīth:

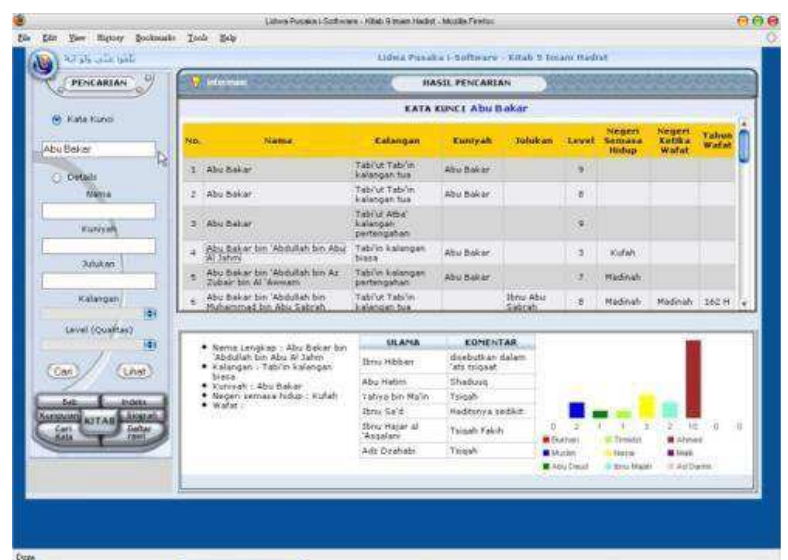

Figure 3. Rawi Names Display

4) We also can choose the menu of collections of hadith in order to know the variation of quality of hadīth, such as maqtu', marfu', mauquf, mu'allaq, munqathi ', mursal, etc: 


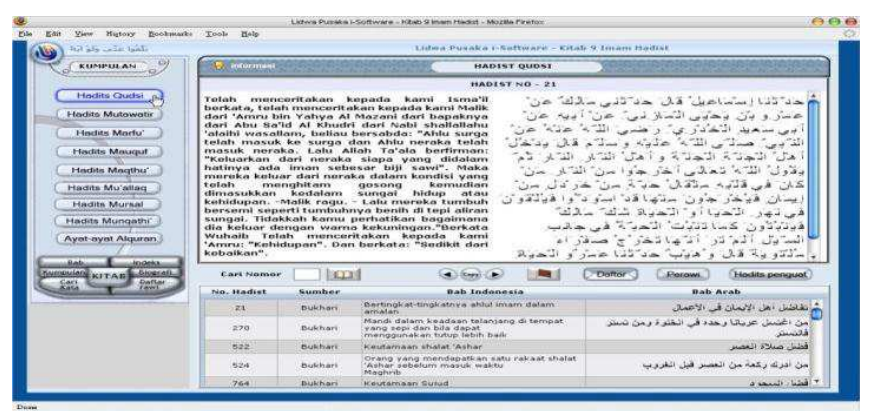

Figure 4. Collections Menu Display

5) Last step is copy the data of hadith that can be pasted into the other application, such microsoft office word.

Another important parts of Lidwa Pusaka application is the menu of science of hadīth or mustalah al-hadith. It is a menu that students can find discussions on the science of hadith briefly [5]

The menu of science of hadīth in Lidwa Pusaka application can be used by students to learn the mustalah al-hadīth. It is an application that supports the learning of hadìth in college and university.

It is interesting that student used the Lidwa Pusaka application in their learnings at UIN Sunan Gunung Djati Bandung. The study focuses on student's satisfaction after used the Lidwa Pusaka in their learnings of hadīth. I distributed five questions to 32 students [6], [8]. They previously were given a task during first half semester to find certain hadìth from the nine books of hadīth at the library. They then was ordered to use Lidwa Pusaka application in second half semester. They should compare how their experiences when use the nine books of hadìth and the Lidwa Pusaka application.

Following list of step that ordered into student to search hadìth:

1) Determining the theme of Hadith Muamalah each one person;

2) Seeking Hadith conventionally by using Mu'jam Mufarras li alfadz al-Hadith;

3) Seeking the quality and quantity of Hadith by looking at Rawi Hadith from Rijal alHadith;

4) While digitally using the search for Hadith, which has been described previously;

After completion of the assignment, at the end of the course the researcher conducted a correspondence on the heirloom as below:

Lidwa (about attached) to 32 students. Then the results are reviewed from the correspondence analysis between software Lidwa Pusaka with satisfaction Student of fourth semester of Hadith Science Department at Faculty of Ushuluddin UIN SGD obtained contingency table:

Table 1. Contingency Table

\begin{tabular}{|l|l|l|l|l|}
\hline \multirow{2}{*}{$\begin{array}{l}\text { Lidwa Pusaka } \\
\text { Application }\end{array}$} & \multicolumn{3}{|c|}{ Student Satisfaction } & \\
\cline { 2 - 4 } & $\begin{array}{c}\text { Very } \\
\text { Satisfied }\end{array}$ & $\begin{array}{c}\text { Enough } \\
\text { Satisfied }\end{array}$ & Not Satisfied & \\
\hline $\begin{array}{l}\text { Searching } \\
\text { Hadith } \\
\text { Particular } \\
\text { Discussion }\end{array}$ & 7 & 2 & 1 & 10 \\
\hline $\begin{array}{l}\text { Musthalah } \\
\text { Hadith }\end{array}$ & 1 & 1 & - & 2 \\
\hline $\begin{array}{l}\text { Explanation of } \\
\text { Quantity- } \\
\text { Quality of } \\
\text { Hadith }\end{array}$ & 6 & 2 & - & 8 \\
\hline Time Efficiency & 5 & - & - & 5 \\
\hline $\begin{array}{l}\text { Efficiency in } \\
\text { Learning } \\
\text { Application }\end{array}$ & 5 & 2 & - & 7 \\
\hline Amount & 24 & 7 & 1 & 32 \\
\hline
\end{tabular}


The chi-square value describes the proximity of each variable. At a chi-square value a positive or negative mark corresponds to the inverse of the sign at the difference value [9]. A positive sign indicates a strong relationship and a negative sign indicates a weak relationship. The value of chi-square between software Lidwa Pusaka with satisfaction Students semester IV Hadith Science Departemen at Faculty Ushuluddin UIN Sunan Gunung Djati Bandung, namely:

Table 2. Chi-Square Result Table

\begin{tabular}{|l|l|l|l|}
\hline \multirow{2}{*}{$\begin{array}{c}\text { Lidwa Pusaka } \\
\text { Application }\end{array}$} & \multicolumn{1}{c|}{$\begin{array}{c}\text { Very } \\
\text { Satisfied }\end{array}$} & $\begin{array}{c}\text { Enough } \\
\text { Satisfied }\end{array}$ & $\begin{array}{c}\text { Not } \\
\text { Satisfied }\end{array}$ \\
\cline { 2 - 4 } & 0,03 & 0,01 & 1,51 \\
\hline $\begin{array}{l}\text { Searching of } \\
\text { Specific Hadith }\end{array}$ & 0,16 & 0,64 & 0,62 \\
\hline $\begin{array}{l}\text { Discussion of } \\
\text { Musthalah Hadith }\end{array}$ & 0 & 0,03 & 0,65 \\
\hline $\begin{array}{l}\text { Explanation of } \\
\text { Quantity-Quality of } \\
\text { Hadith }\end{array}$ & 0,41 & 1,93 & 0,15 \\
\hline $\begin{array}{l}\text { Time Efficiency of } \\
\text { Using Application }\end{array}$ & 0,41 & 1,93 & 0,15 \\
\hline $\begin{array}{l}\text { Time Efficiency in } \\
\text { Dictation of Hadith }\end{array}$ & 4,06 & 0,14 & 0,21 \\
\hline $\begin{array}{l}\text { Efficiency in } \\
\text { Learning } \\
\text { Application }\end{array}$ & & & \\
\hline
\end{tabular}

Meanwhile, if presented by students who feel satisfied that is $75 \%$, feel quite satisfied $21 \%$ and not satisfied $4 \%$ with software Lidwa Pusaka that help in the understanding Hadith and Science of Hadith.

\section{Conclusion}

Lidwa Pusaka application is very effective in supporting the learning hadith among students. There are $75 \%$ of students who satisfied in learning hadīth using the application, $21 \%$ who quite satisfied, and $4 \%$ who did not satisfy. The application could helps student in understanding hadith. It can be considered that there is one student who did not satisfy for every seven students at the university.

\section{References}

[1] C. T. Adhikara, "Analisis Sebaran Pemanfaatan Internet Blog/Weblog untuk Kategori Bisnis dan Ekonomi di Dunia Maya Indonesia," ComTech Comput. Math. Eng. Appl., vol. 1, no. 2, pp. 1188-1196, Dec. 2010.

[2] Idri, Studi Hadis. Jakarta: Kencana, 2010.

[3] T. M. H. A. Shiddieqy, Sejarah dan Pengantar Ilmu Hadis. Semarang: PT. Pustaka Rizki Putra, 1999.

[4] H. H. Batubara, "Pemanfaatan Ensiklopedi Hadis Kitab 9 Imam sebagai Media dan Sumber 
Belajar Hadis," Muallimuna J. Madrasah Ibtidaiyah, vol. 2, no. 2, pp. 63-74, 2017.

[5] Lidwa, "Profil Lidwa." [Online]. Available: http://www.lidwa.com/profil-lidwa/. [Accessed: 29-Oct-2018].

[6] M. Greenacre, Correspondence Analysis In Practice. New York: Chapman \& Hall/CRC, 2007.

[7] D. U. Fikriyyah, "Telaah Aplikasi Hadis (Lidwa Pusaka)," J. Stud. Ilmu-Ilmu al-Qur'an dan Hadis, vol. 17, no. 2, pp. 273-288, 2016.

[8] C. Jannah, "Analisis Korespondensi Untuk Mengetahui Alasan Mahasiswa Memilih Jurusan Di Fmipa Universitas Negeri Malang (Studi Kasus Mahasiswa Non Kependidikan FMIPA Universitas Negeri Malang)," Universitas Negeri Malang, 2013.

[9] M. J. F. Hair, Multivariate Data Analysis. New York: Pearson Prentice, 2010. 